ISSN 1420-3049

www.mdpi.com/journal/molecules

Article

\title{
Occurrence and Estimation of trans-Resveratrol in One-Year-Old Canes from Seven Major Chinese Grape Producing Regions
}

\author{
Ang Zhang ${ }^{1}$, Yulin Fang ${ }^{1,2, *}$, Xuan $\mathrm{Li}^{3}$, Jiangfei Meng ${ }^{1}$, Hua Wang ${ }^{1,2}$, Hua Li ${ }^{1,2}$, \\ Zhenwen Zhang ${ }^{1,2}$ and Zhijun Guo ${ }^{1}$ \\ 1 College of Enology, Northwest A\&F University, Yangling, Shaanxi 712100, China \\ 2 Shaanxi Engineering Research Center for Viti-Viniculture, Yangling, Shaanxi 712100, China \\ 3 Department of Biological and Agricultural Engineering, University of California, Davis, One \\ Shields Avenue, CA 95616, USA
}

* Author to whom correspondence should be addressed; E-Mail: fangyulin@nwsuaf.edu.cn; Tel.: +86 29 87091874; Fax: +862987091874.

Received: 10 January 2011; in revised form: 7 March 2011 / Accepted: 9 March 2011 / Published: 31 March 2011

\begin{abstract}
The concentration of trans-resveratrol in 165 grape cane samples from three major grape production regions and four large distribution centers of Chinese wild Vitis species were determined by reversed-phase high-performance liquid chromatography (HPLC). Among the different genotype groups and purpose of uses, cultivars of $V$. vinifera had much higher amounts of trans-resveratrol than did the cultivars of both V. labrusca or $V$. labrusca and $V$. vinifera hybrids, and within the $V$. vinifera species, significantly higher amounts of trans-resveratrol were found in wine grapes compared to table ones. No significant differences were observed between $V$. labrusca and its hybrids from crosses with $V$. vinifera, and between red cultivars and white ones $(P<0.05$ or $P<0.01)$. The contents of trans-resveratrol, as a normal constituent occurring in grape canes, in Chinese wild species of $V$. amurensis, $V$. pentagona, and $V$. davidii from their native habitats were also relatively high.
\end{abstract}

Keywords: trans-resveratrol; grape; one-year-old canes; HPLC 


\section{Introduction}

trans-Resveratrol (3,5,4'-trihydroxystilbene) is a phytoalexin synthesized naturally by several plants in response to pathogen infection, traumatic damage, ultraviolet (UV) irradiation, and other stresses [1-3]. Its occurrence has been documented in a narrow range of dietary sources of which grapes, peanuts, blueberries, strawberries, hops, and their products are the main representatives [4-9]. Moreover, trans-resveratrol has also been produced by chemical synthesis and is sold as a nutritional supplement derived primarily from the Chinese and Japanese folk medicine giant knotweed rhizome [10]. It has gained significant global attention due to its promising biological and pharmacological properties including antioxidant, anticancer, cardioprotective, anti-inflammatory, antiplatelet, antiviral action and life span extension in diverse organisms, from yeast to vertebrates [4,11-17].

Grapes and wine are the primary dietary sources of resveratrol in the human diet. In the past 20 years, China achieved much success in the development of its grape and wine industry. All the cultivated grape cultivars in China are mainly grown in three major regions, indicated as $\mathrm{C} 1, \mathrm{C} 2$, and C3 (Figure 1). Most Chinese wild Vitis species are distributed in four major eco-geographic centers, labeled W1, W2, W3, and W4 (Figure 1).

Figure 1. Geographical location of the sampling sites (black points).

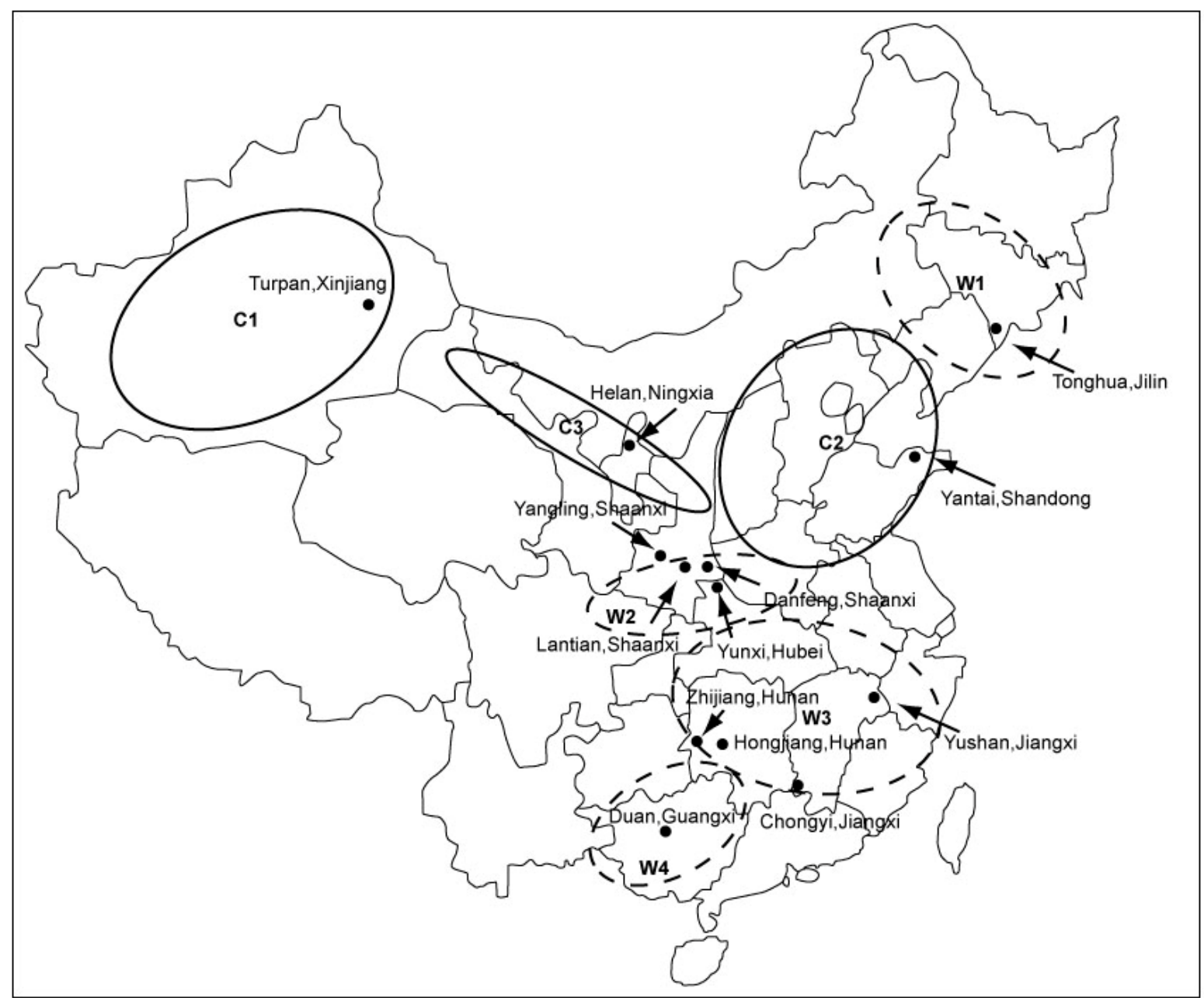


Provinces with a sizeable amount of grape cultivation in China are Xinjiang, Hebei, Shandong, Liaoning and Henan [18]. Additionally, China is one of the most important centers of origin of Vitis species and several wild Chinese Vitis species that occur widely in their native habitats, such as $V$. amurensis in the north-east regions of China, V. davidii and V. pentagona in the southern regions, have been developed to produce wine [19,20]. Large quantities of grape canes are produced as solid wastes during the annual pruning campaigns of the viticulture industry. Compared with other solid byproducts from wineries and vineyards such as grape pomace [21], grape stems [22], grape seeds [23], and so on, people have paid little attention to grape cane wastes with respect to the possible recovery of high value-added compounds. These pruning wastes represent a great potential source of natural antioxidants, and after suitable treatment these low-cost residues could contribute to the sustainable development of related industries. Currently, these grape cane wastes are disposed of in landfills, burned in situ or used as fuels, indicating low-value utilizations [24]. We know of only a few previous studies that have addressed the resveratrol content in a single sample of Pinot Noir (V. vinifera) grape cane $[25,26]$. The diversity of the health-promoting properties of trans-resveratrol has sparked intense research interest devoted to developing resveratrol-enriched foodstuffs or plants and exploiting other new potential sources to meet the increasing demand [27-29].

The main objectives of the present work were: (i) to investigate and evaluate the trans-resveratrol content in one-year-old canes at the grape germplasm level in order to acquire information for the future utilization of these wastes; (ii) to compare grape canes with other main known sources of transresveratrol; (iii) to estimate the annual yield and the potential economic value of trans-resveratrol in grape cane wastes from seven large grape-concentrating areas of China.

\section{Results and Discussion}

\subsection{Genotypic variation of trans-resveratrol contents in grape canes from two germplasm repertoires}

A total of 118 grape cultivars (51 from Yangling and 67 from Yantai), mainly belonging to three important commercial grape groups: V. vinifera, V. labrusca, and V. labrusca and V. vinifera hybrids, were analyzed for trans-resveratrol content. The frequency distribution and median of amounts of trans-resveratrol in one-year-old canes were similar in the two repositories (Figures 2 and 3).

The wine grape cultivars of $V$. vinifera had higher trans-resveratrol contents than other grape genotypic groups in this study in the two repositories. trans-Resveratrol content in wine grape cultivars of $V$. vinifera ranged from 664.7 to $1,751.6 \mathrm{mg} \mathrm{kg}^{-1}$ of cane fresh weight (FW) with a median of $906.6 \mathrm{mg} \mathrm{kg}^{-1}$ of cane FW in Yangling (Figure 2) and from 570.8 to $1,452.9 \mathrm{mg} \mathrm{kg}^{-1}$ of cane FW with a median of $780.9 \mathrm{mg} \mathrm{kg}^{-1}$ of cane $\mathrm{FW}$ in Yantai (Figure 3). The trans-resveratrol concentrations posted by wine grape cultivars of $V$. vinifera varied significantly with their genetic backgrounds. The highest value was found in 'Pinot Noir', one of the most famous wine grape cultivars, reaching 1,751.6 and $1,452.9 \mathrm{mg} \mathrm{kg}^{-1}$ of cane FW in Yangling and Yantai, respectively. It is somewhat similar to the previous reports that the highest trans-resveratrol concentrations were also found in red wines from cv. 'Pinot Noir' [30,31]. 
Figure 2. Box and whisker plots of Yangling Grape Germplasm Repository. The median and mean value are indicated by the horizontal bar and the plus sign inside the box, respectively; the height of the box represents the interquartile range (IQR), which is the difference between the third quartile and the first quartile of the data. The whisker (the vertical lines from the top and bottom of the box) extends to a distance of 1.5 times IQR. Data outside these whiskers are marked by the black dots. The numbers in front of the black dots represent the accession numbers (Table 1). V-T, table grape cultivars of $V$. vinifera; V-W, wine grape cultivars of $V$. vinifera; LV-T, table grape cultivars of hybrids between $V$. labrusca and $V$. vinifera; AL-T, table grape of hybrid between $V$. aestivalis and $V$. labrusca; R-T, table grape of $V$. rotundifolia.

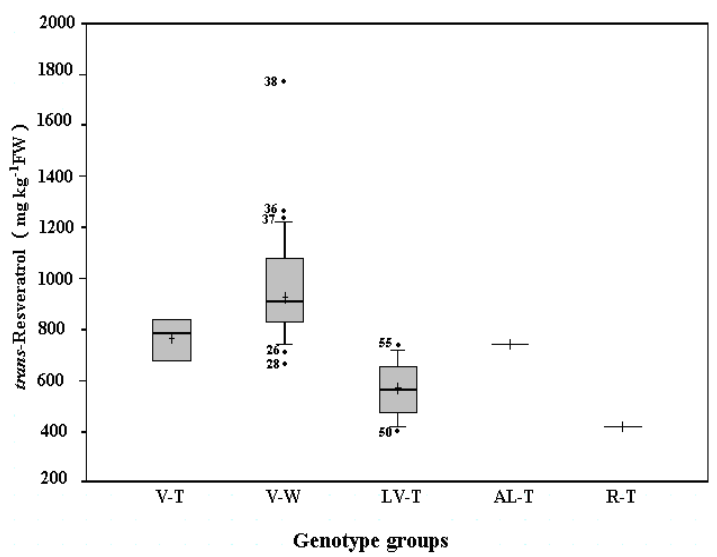

Figure 3. Box and whisker plots of Yantai Grape Germplasm Repository. The median and mean value are indicated by the horizontal bar and the plus sign inside the box, respectively. The height of the box represents the interquartile range (IQR), which is the difference between the third quartile and the first quartile of the data. The whisker (the vertical lines from the top and bottom of the box) extends to a distance of 1.5 times IQR. Data outside these whiskers are marked by the black dots. The numbers in front of the black dots represent the accession numbers (Table 1). V-T, table grape cultivars of $V$. vinifera; $\mathrm{V}-\mathrm{W}$, wine grape cultivars of $V$. vinifera; LV-T, table grape cultivars of hybrids between $V$. labrusca and $V$. vinifera; L-J, juice grape cultivars of $V$. labrusca; VR-W, wine grape cultivar of hybrid between V.vinifera and V. riparia. LR-Rs, rootstock grape cultivar of hybrid between $V$. labrusca and $V$. riparia.

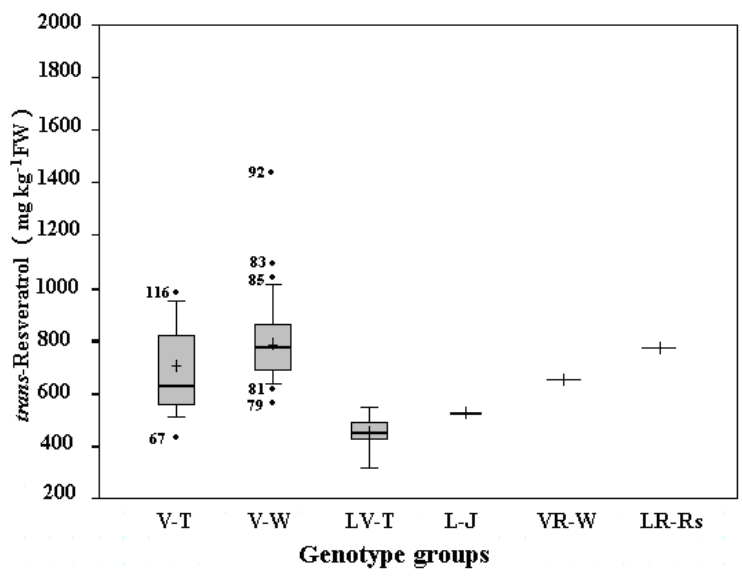


Other wine grapes also produced quite high values, such as 'Cabernet Gernischt' and 'Cabernet Sauvignon' from Yangling and 'Riesling' and 'Silvaner' from Yantai, reaching 1,273.4 and $1,238.6 \mathrm{mg} \mathrm{kg}^{-1}$ of cane $\mathrm{FW}$ and $1,072.2$ and $1,027.4 \mathrm{mg} \mathrm{kg}^{-1}$ of cane $\mathrm{FW}$, respectively. 'MüllerThurgau' from Yangling and 'Jiubai' from Yantai were found to have the lowest values of 664.7 and $570.8 \mathrm{mg} \mathrm{kg}^{-1}$ of cane $\mathrm{FW}$, respectively.

Table 1. Locations and characteristics of grape cultivars used in this study.

\begin{tabular}{|c|c|c|c|c|c|}
\hline Locations & Species $^{\mathrm{a}}$ & Color & Usage & No. & Cultivars or Genotypes ${ }^{\mathrm{c}}$ \\
\hline \multirow[t]{2}{*}{ Turpan } & $\mathrm{V}$ & Green & Raisin & 3 & Centennial Seedless (1), Manaizi (2), Thompson Seedless (3) \\
\hline & & Red & Raisin & 4 & $\begin{array}{l}\text { Crimson Seedless (4), Monukka (5), Ruby Seedless (6), } \\
\text { Munage (7) }\end{array}$ \\
\hline \multirow[t]{2}{*}{ Helan } & $\mathrm{V}$ & Green & Wine & 1 & Chardonnay (8) \\
\hline & & Red & Wine & 7 & $\begin{array}{l}\text { Cabernet Franc (9), Cabernet Gernischt (10), Cabernet } \\
\text { Sauvignon (11), Merlot (12), Syrah (13), Pinot Noir (14), } \\
\text { Gamay (15) }\end{array}$ \\
\hline \multirow[t]{8}{*}{ Yangling } & $\mathrm{V}$ & Green & Table & 2 & Pearl of Csaba (16), Queen of the Vineyard (17) \\
\hline & & & Wine & 15 & $\begin{array}{l}\text { Aligoté (18), Angelina (19), Augusta (20), Baibigebuer (21), } \\
\text { Baidehai (22), Bourboulenc (23), Chardonnay (24), Ecoly (25), } \\
\text { Gouais Blanc (26), Itlian Riesling (27), Müller-Thurgau (28), } \\
\text { Petit Manseng (29), Pollux (30), Sauvignon Blanc (31), } \\
\text { Semillon (32) }\end{array}$ \\
\hline & & Red & Wine & 16 & $\begin{array}{l}8804 \text { (33), Blue French (34), Cabernet Franc (35), Cabernet } \\
\text { Gernischt (36), Cabernet Sauvignon (37), Pinot Noir (38), Syrah } \\
\text { (39), Gamay (40), Merlot (41), Granoir (42), Gewürztraminer } \\
\text { (43), Muscat Hamburg (44), Carignane (45), Cinsaut (46), } \\
\text { Zinfandel (47), Roussanne Du Var (48) }\end{array}$ \\
\hline & & & Table & 1 & Shandongzaohong (49) \\
\hline & LV & Green & Table & 2 & Golden Queen (50), Hakuho (51) \\
\hline & & Red & Table & 13 & $\begin{array}{l}\text { Beni Zuiho (52), Hutai8 (53), Ikawa1014 (54), Ikawa1025 (55), } \\
\text { Iona (56), Izunishiki (57), Kyoho (58), Campbell Early (59), } \\
\text { Alirobar (60), Beni Fuji (61), Honey Red (62), Jasmine (63), } \\
\text { Tensyu (64) }\end{array}$ \\
\hline & AL & Red & Table & 1 & Conquistador (65) \\
\hline & $\mathrm{R}$ & Red & Table & 1 & Alachua (66) \\
\hline \multirow[t]{3}{*}{ Yantai } & $\mathrm{V}$ & Green & Table & 7 & $\begin{array}{l}\text { Victoria Blanc (67), Autumn White (68), Xiabai (69), Zaobai } \\
\text { (70), Jingyu (71), Niunai (72), Zexiang ( } 73 \text { ) }\end{array}$ \\
\hline & & & Wine & 13 & $\begin{array}{l}\text { Chardonnay (74), Chenin Blanc (75), Colombard (76), Gamay } \\
\text { Blanc (77), Grenache Blanc (78), Jiubai (79), Muscat Blanc } \\
\text { (80), Muscat of Alexandria (81), Pinot Blanc (82), Riesling } \\
\text { (83), Rkatsiteli (84), Silvaner (85), Ugni Blanc (86) }\end{array}$ \\
\hline & & Red & Wine & 20 & $\begin{array}{l}\text { Cabernet Franc (87), Cabernet Gernischt (88), Cabernet } \\
\text { Sauvignon (89), Gamay (90), Merlot (91), Pinot Noir (92), } \\
\text { Syrah (93), Nebbiolo (94), Petit Verdot (95), Pinot Gris (96), } \\
\text { Mission (97), Ruby Cabernet (98), Sangiovese (99), Saperavi } \\
\text { (100), Noir de Maisky (101), Flame Muscat (102), Alicante } \\
\text { Bouschet (103), Yan73 (104), Yan74 (105), Jasmin (106) }\end{array}$ \\
\hline
\end{tabular}


Table 1. Cont.

\begin{tabular}{|c|c|c|c|c|c|}
\hline & & & Table & 14 & $\begin{array}{l}\text { Autumn Black (107), Autumn Royal (108), Black Rose (109), } \\
\text { Heijixin (110), Jingxiu (111), Guibao (112), Lungyen (113), } \\
\text { Manicure Finger (114), Muscat Mathiasz Janosne (115), } \\
\text { Fenghuang } 51 \text { (116), Hongxiangjiao (117), Rizamat (118), Red } \\
\text { Globe (119), Red Guibao (120) }\end{array}$ \\
\hline & \multirow[t]{2}{*}{ LV } & Green & Table & 1 & Triumph (121) \\
\hline & & Red & Table & 8 & $\begin{array}{l}\text { Fujiminori (122), Jingya (123), Jingyou (124), Meiguilu (125), } \\
\text { Olympia Black (126), Takasumi (127), Wase Takasumi (128), } \\
\text { Fox (129) }\end{array}$ \\
\hline & \multirow[t]{2}{*}{$\mathrm{L}$} & Green & Juice & 1 & Moore's Diamond (130) \\
\hline & & Red & Juice & 1 & Concord (131) \\
\hline & VR & Red & Wine & 1 & Bacco Noir (132) \\
\hline & LR & Red & $\mathrm{Rs}^{\mathrm{b}}$ & 1 & Beta (133) \\
\hline Lantian & $\mathrm{P}$ & Red & Wine $^{\S}$ & 3 & Lantian1 (134), Lantian2 (135), Wangshunshan (136) \\
\hline \multirow[t]{2}{*}{ Danfeng } & $\mathrm{P}$ & Green & Wine $^{\S}$ & 1 & Danfeng2 (137) \\
\hline & & Red & Wine $^{\S}$ & 1 & Danfeng1 (138) \\
\hline Yunxi & $\mathrm{P}$ & Red & Wine $^{\S}$ & 3 & Yunxi1 (139), Yunxi2 (140), Yunxi3 (141) \\
\hline Duan & $\mathrm{P}$ & Red & Wine ${ }^{\S}$ & 3 & Douan1 (142), Douan2 (143), Douan3 (144) \\
\hline Zhijiang & $\mathrm{D}$ & Red & Wine $^{\S}$ & 3 & Gaoshan-1 (145), Gaoshan-2 (146), Shuijing Brier (147) \\
\hline Hongjiang & $\mathrm{D}$ & Red & Wine $^{\S}$ & 2 & Xuefengshan1 (148), Xuefengshan2 (149) \\
\hline \multirow[t]{2}{*}{ Chongyi } & $\mathrm{D}$ & Green & Wine $^{\S}$ & 1 & Baiyu (150) \\
\hline & & Red & Wine $^{\S}$ & 4 & Chongyil (151), Chongyi2 (152), Chongyi3 (153), Junzi (154) \\
\hline Yushan & $\mathrm{D}$ & Red & Wine $^{\S}$ & 1 & Tangwei (155) \\
\hline \multirow[t]{3}{*}{ Tonghua } & LV & Green & Wine & 1 & Vidal Blanc (156) \\
\hline & AM & Red & Wine & 5 & $\begin{array}{l}\text { Shuanghong (157), Shuangyou (158), Tonghual (159), } \\
\text { Zuoshan1 (160), Zuoshan2 (161) }\end{array}$ \\
\hline & VAM & Red & Wine & 4 & $\begin{array}{l}\text { Beichun (162), Beihong (163), Gongniang1 (164), Gongniang2 } \\
\text { (165) }\end{array}$ \\
\hline
\end{tabular}

\footnotetext{
${ }^{\mathrm{a}} \mathrm{V}, \mathrm{V}$. vinifera; LV, V. labrusca $\times$ V. vinifera; AL, V. aestivalis $\times$ V. labrusca; R, V. rotundifolia; L, V. labrusca; VR, V. vinifera $\times$ V. riparia; LR, V. labrusca. $\times$ V. riparia; P, Vitis pentagona; D, V. davidii; AM, $V$. amurensis; VAM, V.vinifera $\times$ V. amurensis; ${ }^{b}$ Rs, Rootstock; ${ }^{c}$ Number in parentheses following the cultivar indicates the serial number; ${ }^{\S}$ These cultivars are already used as wine grapes or show a great potential for making wine.
}

The contents of trans-resveratrol in the analyzed $V$. vinifera table grapes from Yangling and Yantai were in the range of 671.2 to $841.8 \mathrm{mg} \mathrm{kg}^{-1}$ of cane $\mathrm{FW}$ with a median of $782.4 \mathrm{mg} \mathrm{kg}^{-1}$ of cane FW; and 434.5 to $980.9 \mathrm{mg} \mathrm{kg}^{-1}$ of cane FW with a median of $633.4 \mathrm{mg} \mathrm{kg}^{-1}$ of cane FW, respectively. For the $V$. vinifera table grapes from the Yangling Grape Germplasm Repository the highest value was found in $\mathrm{cv}$. 'Shandongzaohong' ( $841.8 \mathrm{mg} \mathrm{kg}^{-1}$ of cane $\mathrm{FW}$ ), while the lowest one found in $\mathrm{cv}$. 'Queen of the Vineyard' (671.2 $\mathrm{mg} \mathrm{kg}^{-1}$ of cane FW). Three cultivars from Yantai containing higher levels of trans-resveratrol were 'Fenghuang 51' (980.9 $\mathrm{mg} \mathrm{kg}^{-1}$ of cane FW), 'Autumn Royal' (952.4 $\mathrm{mg} \mathrm{kg}^{-1}$ of cane FW), and 'Muscat Mathiasz Janosne' (946.9 $\mathrm{mg} \mathrm{kg}^{-1}$ of cane FW). The transresveratrol content in 'Victoria Blanc' from Yantai was found to have the lowest value of $434.5 \mathrm{mg} \mathrm{kg}^{-1}$ of cane FW. 
Compared with other grape genotypic groups, table grape cultivars of $V$. labrusca and $V$. vinifera hybrids in both grape repositories in this study had much lower trans-resveratrol contents. The contents of trans-resveratrol in table grapes ranged from 396.8 to $722.9 \mathrm{mg} \mathrm{kg}^{-1}$ of cane FW with a median of $564.2 \mathrm{mg} \mathrm{kg}^{-1}$ of cane FW in Yangling and from 320.6 to $549.3 \mathrm{mg} \mathrm{kg}^{-1}$ of cane FW with a median of $450.8 \mathrm{mg} \mathrm{kg}^{-1}$ of cane $\mathrm{FW}$ in Yantai. The cultivars 'Ikawa 1025' from Yangling and 'Takasumi' from Yantai had the highest amounts of trans-resveratrol among table grapes, and their concentrations were 722.9 and $549.3 \mathrm{mg} \mathrm{kg}^{-1}$ of cane $\mathrm{FW}$, respectively. The lowest values were in the cultivar of 'Golden Queen' (396.8 mg kg-1 of cane FW) from Yangling and 'Triumph' (320.6 mg kg of cane FW) from Yantai.

Only the table grape cultivar 'Conquistador', a hybrid between $V$. aestivalis and $V$. labrusca from the Yangling Grape Germplasm Repository, had a similar trans-resveratrol amount to the median of the table grapes of $V$. vinifera from the same repository. 'Alachua', the other table grape cultivar of $V$. rotundifolia from Yangling, had a relatively low value of $416.8 \mathrm{mg} \mathrm{kg}^{-1}$ of cane FW. The transresveratrol contents were 576.5 and $467.4 \mathrm{mg} \mathrm{kg}^{-1}$ of cane FW for 'Moore's Diamond' and 'Concord', two juice cultivars of $V$. labrusca from Yantai, respectively. 'Bacco Noir', a wine grape from Yantai, a $V$. vinifera and $V$. riparia hybrid, posted a value of $694.3 \mathrm{mg} \mathrm{kg}^{-1}$ of cane $\mathrm{FW}$. A relatively high amount of trans-resveratrol was found in the only rootstock cultivar 'Beta' in Yantai, a hybrid between V. labrusca and V. riparia, reaching $773.5 \mathrm{mg} \mathrm{kg}^{-1}$ of cane $\mathrm{FW}$.

The average trans-resveratrol contents in grape canes of the two grape germplasm collections are listed in Table 2, based on the classifications by different genotypes ( $V$. vinifera, $V$. labrusca, or $V$. labrusca and $V$. vinifera hybrids), different fruit traits (red, including all rouge, purple, and noir cultivars; or green, including all yellow cultivars), and different uses (table, wine, or juice grapes). Further statistical analysis showed that there were significant differences in the amounts of transresveratrol in grape canes within and among different groups and similar variations in the corresponding groups from the two grape germplasm collections (Table 2).

For all grape cultivars of three species in this study the average trans-resveratrol content in grapes of $V$. vinifera was $937.9 \mathrm{mg} \mathrm{kg}^{-1}$ of cane $\mathrm{FW}$, and significantly higher than that $\left(571.3 \mathrm{mg} \mathrm{kg}^{-1} \mathrm{of}\right.$ cane FW) of the $V$. labrusca and $V$. vinifera hybrids in Yangling $(P<0.05$ and $P<0.01)$. The cultivars of $V$. vinifera from Yantai had significantly higher amounts of trans-resveratrol than did both $V$. labrusca and $V$. labrusca and $V$. vinifera hybrids $(P<0.05$ and $P<0.01)$. However, there were no significant differences between cultivars of $V$. labrusca and those of $V$. labrusca and $V$. vinifera hybrids in Yantai. With regard to grape cultivars' purpose of uses both originating from V. vinifera and V. labrusca and $V$. vinifera hybrids, wine grapes had significantly higher trans-resveratrol than did table grapes in both Yangling and Yantai $(P<0.05$ and $P<0.01)$, whereas there were no significant differences between juice cultivars of $V$. labrusca and table cultivars of $V$. vinifera and $V$. labrusca and $V$. vinifera hybrids in Yantai. In addition, no significant differences of trans-resveratrol contents were observed between the red and green cultivars among different species in both Yangling and Yantai (Table 2).

The results of the study on the two grape germplasm repositories indicated that the amounts of trans-resveratrol in one-year-old canes of various cultivars were strongly influenced by their genetic background. trans-Resveratrol synthesis in plants can usually be triggered by exogenous stress factors, such as UV irradiation and the presence of pathogenic fungi, as discussed previously, but its synthesis in grape canes during the dormant season with low fungal infection conditions and weak UV 
irradiation might be a non-specific response to those stresses. Therefore, trans-resveratrol can be considered as a normal constituent of grape canes, as the similar results reported by Langcake and Pryce [32] in the lignified stems of cv. Müller-Thurgau.

Table 2. Comparison of trans-resveratrol contents (mean value \pm S.D., $\mathrm{mg} \mathrm{kg}^{-1}$ of FW) in grape cane among different genotypic groups or purpose of uses of two grape germplasm repositories.

\begin{tabular}{lll}
\hline Genotype group or purpose of use & Yangling & Yantai \\
\hline All cultivars in this study & $816.0 \pm 252.5$ & $706.2 \pm 191.2$ \\
All cultivars of $\mathrm{V}^{\mathrm{a}}$ & $937.9 \pm 210.0^{* * * \mathrm{~T}}$ & $754.9 \mathrm{Aa} \pm 173.4$ \\
All cultivars of $\mathrm{LV}^{\mathrm{b}}$ & $571.3 \pm 103.8$ & $453.1 \mathrm{Bb} \pm 62.5$ \\
All cultivars of L & $-^{\mathrm{d}}$ & $521.9 \mathrm{Bb} \pm 77.1$ \\
All wine grapes of V \& LV & $950.8 \pm 213.7^{* * * \mathrm{~T}}$ & $796.3 \mathrm{Aa} \pm 169.7$ \\
All table grapes of V \& LV & $610.2 \pm 135.9$ & $618.9 \mathrm{Bb} \pm 176.7$ \\
All juice grape of L & $-^{\mathrm{d}}$ & $521.9 \mathrm{Bb} \pm 77.1$ \\
All red cultivars of V \& LV & $843.8 \pm 289.7$ & $733.4 \pm 194.6$ \\
All green cultivars of V \& LV & $796.9 \pm 174.2$ & $668 . .8 \pm 187.9$ \\
All wine grapes of V & $950.7 \pm 213.7^{* \mathrm{~T}}$ & $796.3 \pm 169.7 * \mathrm{~T}$ \\
All table grapes of V & $804.6 \pm 116.4$ & $689.9 \pm 160.8$ \\
\hline
\end{tabular}

The lowercases and uppercases mean significant variation of average trans-resveratrol in grape cane of Yantai Grape Germplasm Repository among different genotypic groups or purpose of uses at $P<0.05$ and $P<0.01$ levels (ANOVA), respectively; and different letters indicate significant variation; ${ }^{\mathrm{a}} \mathrm{V}, \mathrm{V}$. vinifera; ${ }^{\mathrm{b}} \mathrm{LV}$, hybrid of $\mathrm{V}$. labrusca and V. vinifera; ${ }^{\mathrm{c}} \mathrm{L}, \mathrm{V}$. labrusca; ${ }^{\mathrm{d}}$ Not available; ${ }^{\mathrm{T}} *$ and $* * *$ indicate significant difference of average trans-resveratrol in grape cane in the same grape germplasm repository between different genotypic groups or purpose of uses at $P<$ 0.05 and $P<0.01$ levels (Student's $t$-test), respectively.

\subsection{Occurrence and prediction of trans-resveratrol in main grape cultivars from China and comparison with other known sources}

The concentration ranges and averages with standard deviations of trans-resveratrol in the main cultivars from three major grape production areas and four important distribution centers of Chinese wild Vitis species are shown in Table 3. Occurrences of trans-resveratrol in the main known sources and transgenic plants were summarized in Table 4.

Table 3. Occurrence and potential value estimation of trans-resveratrol in main grape cultivars from seven major grape production regions.

\begin{tabular}{|c|c|c|c|c|c|c|}
\hline $\begin{array}{l}\text { Major } \\
\text { region }\end{array}$ & Usage & Main grape cultivars ${ }^{\mathrm{a}}$ & $\begin{array}{l}\text { trans-Resveratrol } \\
\text { occurrence }^{b}\end{array}$ & Area $^{c}$ & $\begin{array}{l}\text { Predicted } \\
\text { yield }^{\text {d }}\end{array}$ & $\begin{array}{l}\text { Estimated } \\
\text { economic output }^{\mathrm{e}}\end{array}$ \\
\hline$\overline{\mathrm{C} 1}$ & $\begin{array}{l}\text { Table/ } \\
\text { raisin }\end{array}$ & $1,2,3,4,5,6,7$ & $\begin{array}{l}\text { 774.0BCbc } \pm 121.8 \\
(589.9-983.9)\end{array}$ & 96.2 & $\begin{array}{l}74.5(56.7- \\
94.7)\end{array}$ & $149.0-223.5$ \\
\hline \multirow[t]{2}{*}{$\mathrm{C} 2$} & Wine & $\begin{array}{l}74,75,80,81,83,84,85,86,87 \\
88,89,90,91,92,93,104,105\end{array}$ & $\begin{array}{l}834.1 \mathrm{De} \pm 202.4 \\
(608.9-1452.9)\end{array}$ & 48 & $\begin{array}{l}40.0(29.2- \\
69.7)\end{array}$ & $80.0-120.0$ \\
\hline & Table & $\begin{array}{l}67,70,71,72,73,107,108,110 \\
111,112,113,114,116,117,118 \\
119,121,122,123,124,126,127\end{array}$ & $\begin{array}{l}610.1 \mathrm{Aa} \pm 167.1 \\
(320.6-980.9)\end{array}$ & 100.3 & $\begin{array}{l}61.2(32.2- \\
98.4)\end{array}$ & $122.4-183.6$ \\
\hline
\end{tabular}


Table 3. Cont.

\begin{tabular}{|c|c|c|c|c|c|}
\hline \multirow[t]{2}{*}{$\overline{\mathrm{C} 3}$} & Wine & $\begin{array}{l}8,9,10,11,12,13,14,15,27,28,937.8 \mathrm{CDcd} \pm 175.7 \\
31,34,44,45,47 .\end{array}$ & 20 & $\begin{array}{l}18.8(15.3- \\
27.4)\end{array}$ & $37.6-56.4$ \\
\hline & Table & $\begin{array}{ll}16,17,49,50,51,52,53,57,58, & 613.3 \mathrm{Aa} \pm 155.4 \\
59,61,64 . & (396.3-881.9)\end{array}$ & 15.9 & $9.8(6.3-14.0)$ & $19.6-29.4$ \\
\hline W1 & Wine & $\begin{array}{l}157,158,159,160,161,162,163,889.7 \mathrm{CDde} \pm 62.2 \\
164,165 . \\
(818.7-964.6)\end{array}$ & 40 & $\begin{array}{l}35.6(32.7- \\
38.6)\end{array}$ & $71.2-106.8$ \\
\hline W2 & Wine $^{\S}$ & $\begin{aligned} 134,135,136,138,139,140,141 . & 700.6 \mathrm{ABab} \pm 64.9 \\
& (564.6-767.8)\end{aligned}$ & 4.8 & $3.4(2.7-3.7)$ & $6.8-10.2$ \\
\hline W3 & Wine $^{\S}$ & 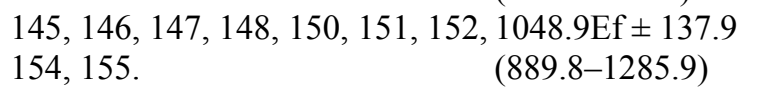 & 19.3 & $\begin{array}{l}20.2(17.2- \\
24.8)\end{array}$ & $40.4-60.6$ \\
\hline W4 & Wine $^{\S}$ & $\begin{array}{ll}142,143,144 . & 838.8 \mathrm{CDcd} \pm 30.9 \\
& (823.5-850.4)\end{array}$ & 10 & $8.4(8.2-8.5)$ & $16.8-25.2$ \\
\hline Sum. ${ }^{f}$ & & & 354.5 & $\begin{array}{l}271.9(200.5- \\
379.8)\end{array}$ & $543.8-815.7$ \\
\hline
\end{tabular}

The lowercases and uppercases mean significant variation at 0.05 and 0.01 level, respectively; and the values in any two groups with different letters indicate significant variation $(\mathrm{P}<0.05$ or $\mathrm{P}<0.01) ;{ }^{\mathrm{a}}$ The numbers in the following blanks represent the same accession numbers to Tab. $1 ;^{\mathrm{b}}$ Mean values \pm S.D., range values in parenthesis, all values in $\mathrm{mg} \mathrm{kg}^{-1}$ of cane $\mathrm{FW}$; ${ }^{\mathrm{c}}$ Data of cultivated area of each major region (MOA, 2006), all values in kha; ${ }^{\mathrm{d}}$ Mean values \pm S.D., range values in parenthesis, all values in ton of trans-resveratrol year ${ }^{-1}$; ${ }^{\mathrm{e}}$ Estimated economic output range values of each major region, all values in US \$ million year ${ }^{-1} ;{ }^{\mathrm{f}}$ Summation, range values in parenthesis; ${ }^{\S}$ These cultivars are already used as wine grapes or show a great potential for making wine.

Table 4. Occurrence of trans-resveratrol in the main known sources.

\begin{tabular}{llcl}
\hline Sources & Cultivars or types & trans-Resveratrol & Ref. \\
\hline Polygonum cuspidatum & R. japonica & $64^{\mathrm{d}}$ & {$[10]$} \\
& R. $\times$ bohemica & $23^{\mathrm{d}}$ & \\
& R. sachalinensis & $29^{\mathrm{d}}$ & \\
& HZ, MB & $3770^{\mathrm{d}}, 2960^{\mathrm{d}}$ & {$[37]$} \\
Grape juice & Palomino fino & $2.4^{1}$ & {$[5]$} \\
Grape berry & Muscadine & $5.2-26.4^{\mathrm{f}}$ & {$[42]$} \\
Grape seed & Gamay & $3.9^{\mathrm{f}}$ & {$[43]$} \\
& Pinot Noir & $588^{\mathrm{d}}$ & {$[23]$} \\
Grape skin & Pinot Noir & $118^{\mathrm{d}}$ & {$[23]$} \\
& Gamay & $6.8^{\mathrm{f}}$ & {$[43]$} \\
Grape pomace & Palomino fino & $15.7^{\mathrm{f}}$ & {$[5]$} \\
& Palomino fino & $192^{\mathrm{d}}$ & {$[21]$} \\
Red wine & Muscadine & $22.1-84.2^{\mathrm{d}}$ & {$[42]$} \\
& Muscadine & $0.4-2.0^{1}$ & {$[42]$} \\
White wine & Other red wine & $0.2-14.3^{\mathrm{a}}$ & {$[30]$} \\
Peanut & White wines & $\approx 0.1^{\mathrm{b}}$ & {$[31]$} \\
& Jinpoong & $1.3^{\mathrm{f}}$ & {$[3]$} \\
& NC-7, Çom, Gazipaşa, Florispan & $0.03-1.92^{\mathrm{d}}$ & {$[44]$} \\
Peanut root & Çerezlik 5025, Çerezlik PI-355276 & & \\
& Other peanut cultivars & $0.02-1.79^{\mathrm{d}}$ & {$[6]$} \\
& Jinpoong & $1.19^{\mathrm{f}}$ & {$[3]$} \\
& Tainan 9, Tainan 11, Tainan 12 & $15-1330^{\mathrm{d}}$ & {$[29]$} \\
\hline
\end{tabular}


Table 4. Cont.

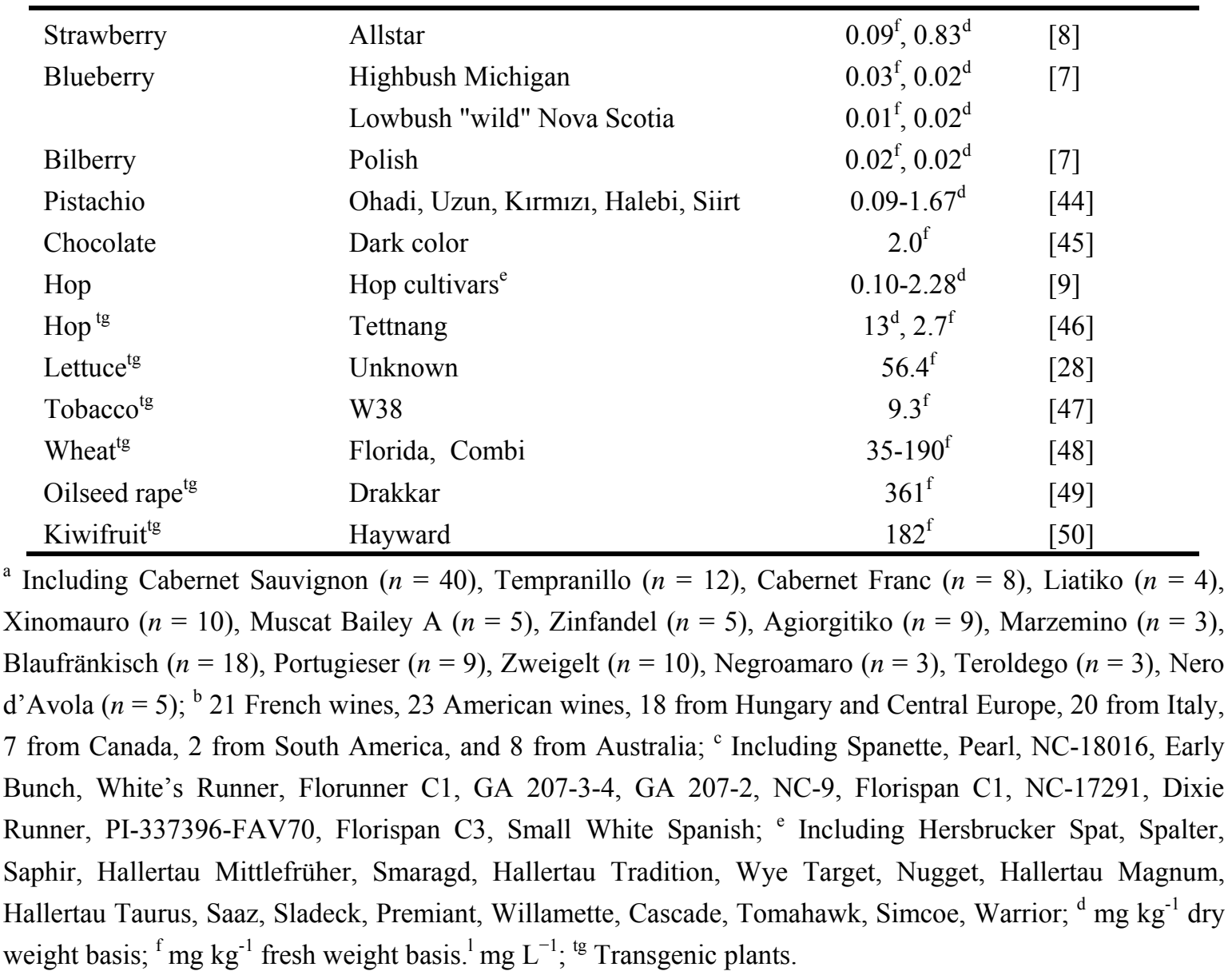

The observed trans-resveratrol contents in grape canes were higher than the reported amounts in most of the other known sources, with a few exceptions (Tables 3, 4). Furthermore, trans-resveratrol occurs in Polygonum cuspidatum and peanut roots in the range from a few tens to a few thousands $\mathrm{mg} \mathrm{kg}{ }^{-1}$ dry weight, showing a marked fluctuations appearing to be related to various factors $[10,37,29]$. In contrast, grape canes represent a novel and stable source of trans-resveratrol.

In this study, 165 grape cane samples were used to estimate the annual yields and the economic outputs of trans-resveratrol from grape cane wastes of seven major grape production regions of China (Table 3). Predicted annual yields of trans-resveratrol from each region were calculated with the mean and range values shown in Table 3, with an approximate annual grape cane production rate of $1 \mathrm{tha}^{-1}$ [38] and cultivated area of each major production region [39]. Estimated annually economic outputs of each region were generated from the average yields values of trans-resveratrol, at a commercial price of food-grade product ranging from US\$2,000 to US\$3,000 kg-1 reported by Baur and Sinclair when they evaluated the costs of daily or yearly trans-resveratrol intake for a human [40]. The total value of trans-resveratrol from grape cane wastes in China could reach up to US\$ 543.8-815.7 million year ${ }^{-1}$ based on cultivation data of 2006. Actually, the vineyard area in China, with a steady increase year after year, reached approximately 475 mha in 2009 [41]. Recovery and utilization of trans-resveratrol from these agricultural pruning wastes, as a sideline production, indicates a huge economic potential. 


\section{Experimental}

\subsection{Plant material}

One hundred and sixty five (165) grape cane samples used in this study (Table 1), including seven raisin grapes of $V$. vinifera from Turpan, Xinjiang (C1), eight wine grapes of $V$. vinifera from Helan, Ningxia (C2), 51 grape cultivars from the experimental vineyard of grape germplasm repository of College of Enology, Northwest A\&F University at Yangling, Shaanxi (C2), 67 grape cultivars from the grape germplasm collection of Changyu Pioneer Wine Co. Ltd in Yantai, Shandong Province (C3), one wine grape hybrid of $V$. labrusca and $V$. vinifera, five wine grapes of $V$. amurensis, and four wine grape hybrids of $V$. vinifera and $V$. amurensis from Tonghua, Jilin (W1), 11 genotypes of $V$. pentagona from Lantian, Shaanxi, Danfeng, Shaanxi, and Yunxi, Hubei, and Douan, Guangxi (W2, W4), 11 grape cultivars or genotypes of $V$. davidii from Zhijiang, Hunan, Hongjiang, Huan, Chongyi, Jiangxi, and Yushan, Jiangxi (W3). The ideal one-year-old canes with moderate growth vigor (approximately $0.8-1.0 \mathrm{~cm}$ diameter) were collected from the above locations during the 2008 pruning practice. All cane samples were frozen in liquid nitrogen, ground through a $0.5 \mathrm{~mm}$ sieve using an electrical grinder (final particle size $<0.5 \mathrm{~mm}$ ), stored under vacuum in labeled plastic containers, and then stored at $-20{ }^{\circ} \mathrm{C}$ in a freezer until extraction.

\subsection{Chemicals}

trans-Resveratrol standard (purity $>97 \%$ ) was purchased from Sigma-Aldrich Chemical Co. (Shanghai, China). Methanol and acetonitrile were HPLC grade solvents from Tianjin Kermel Chemical Reagent Co. Ltd. (Tianjin, China). Analytical grade acetic acid was from Xi'an Chemistry Factory (Xi'an, China). Water was purified using the Milli-Q system (Millipore, Bedford, MA, USA).

\subsection{Extraction of trans-resveratrol from grape canes}

Triplicate samples of ground grape cane (5 g, fresh weight) were extracted three times with acidified methanol solution (40 mL, $1 \mathrm{~N} \mathrm{HCl} / \mathrm{methanol} /$ water, 1/80/19, v/v/v), and extraction was performed under continuous stirring $(600 \mathrm{rpm})$ at $20{ }^{\circ} \mathrm{C}$ for $1 \mathrm{~h}$ in an external water bath. The extracts were centrifuged at $8,000 \mathrm{~g}$ for $15 \mathrm{~min}$ at $4{ }^{\circ} \mathrm{C}$ using a Sorvall RC-5C Plus centrifuge (Kendro Laboratory Products, Newton, CT, USA). All the supernatants were combined in a $250 \mathrm{~mL}$ flask and concentrated in a Büchi RE-111 evaporator (Switzerland) at $35{ }^{\circ} \mathrm{C}$ to a volume of $10 \mathrm{~mL}$. The final concentrate solution was filtered through a $0.22 \mu \mathrm{m}$ nylon micro-membrane and stored at $-40{ }^{\circ} \mathrm{C}$ until analysis.

\subsection{Chromatographic analysis}

The chromatographic analyses were carried out on a Shimadzu liquid chromatograph system (Shimadzu Corp, Kyoto, Japan) equipped with a quaternary pump coupled with a photodiode array detector and a UV-Vis detector. 
Samples were injected onto a Shim-Pack VP-ODS $\mathrm{C}_{18}$ column $(250 \mathrm{~mm} \times 4.6 \mathrm{~mm}, 5 \mu \mathrm{m})$ at room temperature. The mobile phase was acidified water containing $3 \%$ acetic acid (A) and acetonitrile (B). The gradient program is as follows: $\mathrm{B}: 0.00-5.00 \mathrm{~min}, 0-8.5 \%$; $5.00-16.50 \mathrm{~min}, 8.5-2.0 \%$; 16.50-35.00 min, 2.0-18\%; 35.00-50.00 min, 18-20\%; 50.00-65.00 min, 20-30\%; 65.00-70.00 min, $30-0 \%$. The column held at $30{ }^{\circ} \mathrm{C}$ was flushed at a flow rate of $0.8 \mathrm{~mL} / \mathrm{min}$. The DAD detector was applied to ascertain the maximum absorbance wavelength of trans-resveratrol within a range of 200 to $400 \mathrm{~nm}$. The UV-vis detector was conducted at $306 \mathrm{~nm}$ for quantitation of trans-resveratrol in grape cane extracts with the external standard. Chromatographic identification and confirmation of transresveratrol were based on comparing retention times with the authentic standard and on-line UV absorption spectrum data. Results were acquired and processed by the Shimadzu Workstation CLASSVP 6.12 software (Shimadzu Corp, Kyoto, Japan). Typical HPLC chromatographies of grape cane extracts and trans-resveratrol standard are shown in Figure 4.

Figure 4. Typical HPLC chromatographies of grape cane extracts (top) and transresveratrol standard (bottom) captured at $306 \mathrm{~nm}$.

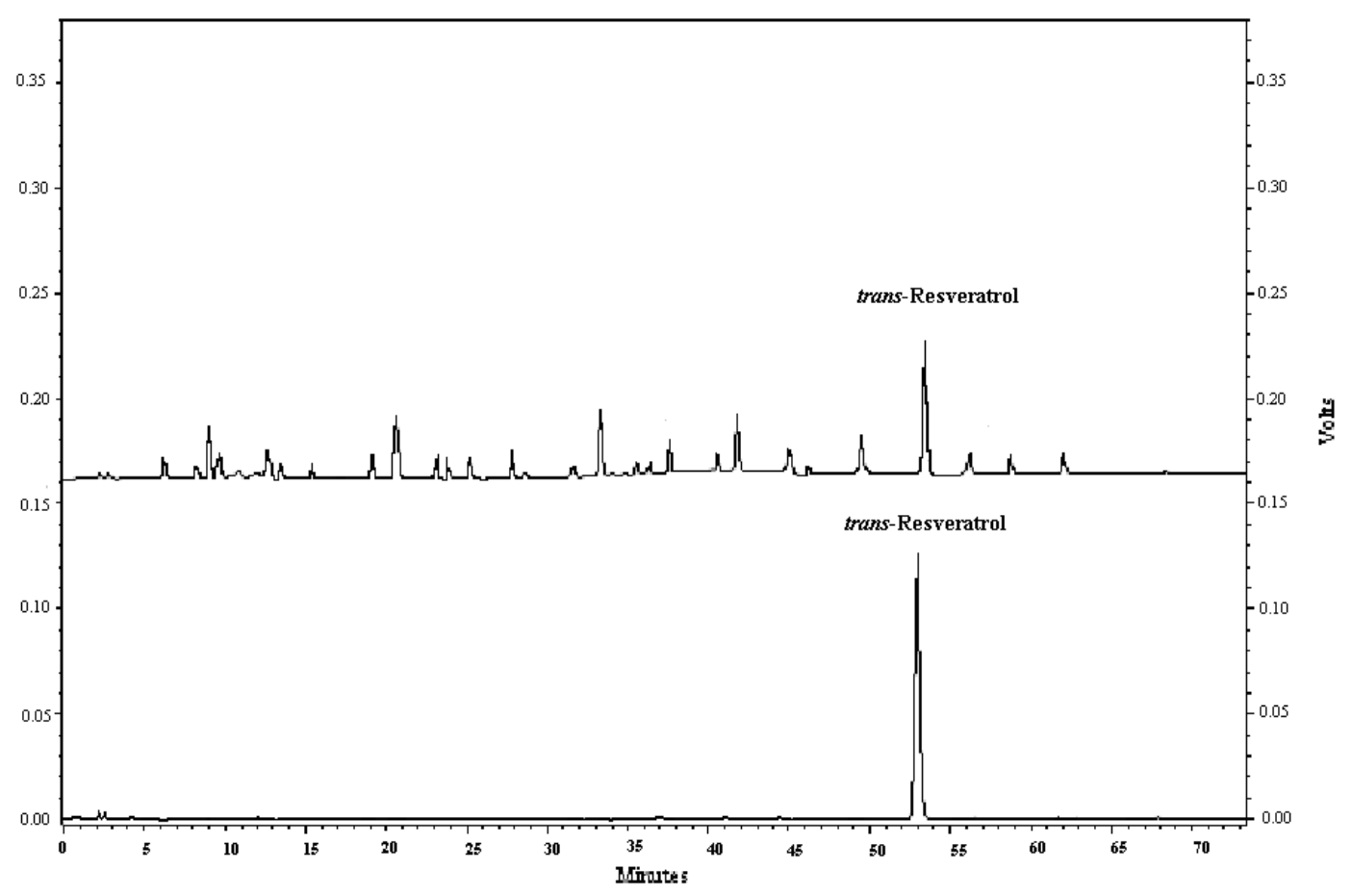

\subsection{Statistical analysis}

Mean values of each grape cane sample were from three replicates, and were employed for further analysis. For the data of two grape germplasm repositories, the cultivar variations of trans-resveratrol contents in one-year-old canes were evaluated at the germplasm level, and the box-and-whisker plots, which are helpful in interpreting the distribution of data, were generated by the software of Sigmaplot version 10.0 (Systat Software Inc., US) to display range, median, and distribution density of variables in sample size. The Student's independent-sample $t$-test and one-way analysis of variance (ANOVA) were carried out by SPSS version 10.0 (SPSS, Inc., Chicago, IL, USA) 


\section{Conclusions}

Grape canes are generated in a substantial quantity as agricultural pruning wastes in the grape industry. trans-Resveratrol has been proven to be a normal constituent of grape canes and its content varies largely with different genotypic groups as well as their purpose of uses. Compared with other known sources, the trans-resveratrol content in grape cane wastes is high enough to indicate they are a potentially new and stable commercial source. Occurrence of trans-resveratrol in main grape cultivars cultivated in seven major grape production regions in China shows a great potential economic value.

\section{Acknowledgements}

The authors would like to thank Changyu Pioneer Wine Co. Ltd in Yantai for its generous donations of grape canes for analysis. We express our gratitude to Northwest A \& F University for the Youth Natural Science Foundation assistance. Also we thank the National Technology System for Grape Industry (nycytx-30-2p-04) for generous financial support of this work.

\section{References and Notes}

1. Cantos, E.; Espin, J.C.; Tomas-Barberan, F.A. Postharvest induction modeling method using UV irradiation pulses for obtaining resveratrol-enriched table grapes: a new "functional" fruit? $J$. Agric. Food Chem. 2001, 49, 5052-5058.

2. Arora, M.K.; Strange, R.N. Phytoalexin accumulation in groundnuts in response to wounding. Plant Sci. 1991, 78, 157-163.

3. Chung, I.M.; Park, M.R.; Chun, J.C.; Yun, S.J. Resveratrol accumulation and resveratrol synthase gene expression in response to abiotic stresses and hormones in peanut plants. Plant Sci. 2003, 164, 103-109.

4. Valenzano, D.R.; Terzibasi, E.; Genade, T.; Cattaneo, A.; Domenici, L.; Cellerino, A. Resveratrol prolongs lifespan and retards the onset of age-related markers in a short-lived vertebrate. Curr. Biol. 2006, 16, 296-300.

5. Roldán, A.; Palacios, V.; Caro, I.; Pérez, L. Resveratrol Content of Palomino fino Grapes: Influence of Vintage and Fungal Infection. J. Agric. Food Chem. 2003, 51, 1464-1468.

6. Sanders, T.H.; McMichael, J.R.W.; Hendrix, K.W. Occurrence of resveratrol in edible peanuts. J. Agric. Food Chem. 2000, 48, 1243-1246.

7. Lyons, M.M.; Yu, C.; Toma, R.B.; Cho, S.Y.; Reiboldt, W.; Lee, J.; Breemen, R.B. Resveratrol in raw and baked blueberries and bilberries. J. Agric. Food Chem. 2003, 51, 5867-5870.

8. Wang, S.Y.; Chen, C.; Wang, C.Y.; Chen, P. Resveratrol content in strawberry fruit is affected by preharvest conditions. J. Agric. Food Chem. 2007, 55, 8269-8274.

9. Jerkovic, V.; Collin, S. Occurrence of resveratrol and piceid in American and European hop cones. J. Agric. Food Chem. 2007, 55, 8754-8758.

10. Vrchotová, N.; Šerá, B.; Tř́ska, J. The stilbene and catechin content of the spring sprouts of Reynoutria species. Acta Chromatogr. 2007, 19, 21-28.

11. Huang, L.M.; Chen, J.K.; Huang, S.S.; Lee, R.S.; Su, M.J. Cardioprotective effect of resveratrol, a natural antioxidant derived from grapes. Cardiovasc. Res. 2000, 47, 549-555. 
12. Puissant, A.; Robert, G.; Fenouille, N.; Luciano, F.; Cassuto, J.P.; Raynand, S.; Auberger, P. Resveratrol promotes autophagic cell death in chronic myelogenous leukemia cells via JNKMediated p62/SQSTM1 expression and AMPK activation. Cancer Res. 2010, 70, 1042-1052.

13. Bertelli, A.A.A.; Das, D.K. Grapes, wines, resveratrols, and heart health. J. Cardiovasc. Pharmacol. 2010, 54, 468-476.

14. Norata, G.D.; Marchesi, P.; Passamonti, S.; Pirilloa, A.; Violi, F.; Catapano, A.L. Antiinflammatory and anti-atherogenic effects of cathechin, caffeic acid and trans-resveratrol in apolipoprotein E deficient mice. Atherosclerosis 2007, 191, 265-271.

15. Bertelli, A.A.; Giovannini, L.; Giannessi, D.; Migliori, M.; Bernini, W.; Fregoni, M.; Bertelli, A. Anti-platelet activity of synthetic and natural resveratrol in red wine. Int. J. Tissue React. 1995, 17, 1-3.

16. Campagna, M.; Rivas, C. Antiviral activity of resveratrol. Boichem. Soc. Trans. 2010, 38 (Pt. 1), $50-53$.

17. Howitz, K.T.; Bitterman, K.J.; Cohen, H.Y.; Lamming, D.W.; Lavu, S.; Wood, J.G.; Zipkin, R.E.; Chung, P.; Kisielewski, A.; Zhang, L.L.; et al. Small molecule activators of sirtuins extend Saccharomyces cerevisiae lifespan. Nature 2003, 425, 191-196.

18. Li, S.H. Grape production in China. In Grape Production in the Asia-Pacific Region, Proceedings of Viticulture (Grape Production) in Asia and the Pacific, Bangkok, Thailand, 2-4 May 2000; Papademetriou, M.K., Dent, F.J., Eds.; FAO Regional Office for Asia and the Pacific: Bangkok, Thailand, 2001; p. 4.

19. Wan, Y.Z.; Schwaninger, H.; Li, D.; Simon, C.J.; Wang, Y.J.; He, P.C. The eco-geographic distribution of wild grape germplasm in China. Vitis 2008, 47, 77-80.

20. Fang, Y.L.; Wang, H.; Zhang, L.; Chang, W.; Xue, F.; Liu, S.W. Effects of different vinifications on aroma components of wild Vitis quinquangularis red wine. Trans. Chin. Soc. Agric. Eng. 2007, 23, 246-250.

21. Casas, L.; Mantell, C.; Rodríguez, M.; de la Ossa, E.J.M.; Roldán, A.; Ory, I., De.; Caro, I.; Blandino, A. Extraction of resveratrol from the pomace of Palomino fino grapes by supercritical carbon dioxide. J. Food Eng. 2010, 96, 304-308.

22. Karvela, E.; Makris, D.P.; Kalogeropoulos, N.; Karathanos, V.T. Deployment of response surface methodology to optimise recovery of grape (Vitis vinifera) stem polyphenols. Talanta 2009, 79, 1311-1321.

23. Casazza, A.A.; Aliakbarian, B.; Mantegna, S.; Cravotto, G.; Perego, P. Extraction of phenolics from Vitis vinifera wastes using non-conventional techniques. J. Food Eng. 2010, 100, 50-55.

24. Garg, V.K.; Gupta, R. Vermicomposting of Agro-Industrial Processing Waste. In Biotechnology for Agro-Industrial Residues Utilisation; Nigam, P.S., Pandey, A., Eds.; Springer: Amsterdam, The Netherlands, 2009; pp. 431-432.

25. Rayne, S.; Karacabey, E.; Mazza, G. Grape cane waste as a source of trans-resveratrol and transviniferin: High-value phytochemicals with medicinal and anti-phytopathogenic applications. Ind. Crop Prod. 2008, 27, 335-340.

26. Zhang, A.; Fang, Y.L.; Wang, H.; Song, J.Q.; Zhang, Y.L.; Song, S.R. Simultaneous determination of individual phenolics in grape tissues by switching detection wavelength in high performance liquid chromatography. Chin. J. Anal. Chem. 2007, 35, 1614-1618. 
27. Guerrero, R.F.; Puertas, B.; Jiménez, M.J.; Cacho. J.; Cantos-Villar, E. Monitoring the process to obtain red wine enriched in resveratrol and piceatannol without quality loss. Food Chem. 2010, 122, 195-202.

28. Liu, S.; Hu, Y.; Wang, X.; Zhong, J.; Lin, Z. High content of resveratrol in lettuce transformed with a stilbene synthase gene of Parthenocissus henryana. J. Agric. Food Chem. 2006, 54, 8082-8085.

29. Chen, R.S.; Wu, P.L.; Chiou, R.Y.Y. Peanut roots as a source of resveratrol. J. Agric. Food Chem. 2002, 50, 1665-1667.

30. Stervbo, U.; Vang, O.; Bonnesen, C. A review of the content of the putative chemopreventive phytoalexin resveratrol in red wine. Food Chem. 2007, 101, 449-457.

31. Goldberg, D.M.; Yan, J.; Eric, Ng.; Diamandis, E.P.; Karumanchiri, A.; Soleas, G.; Waterhouse, A.L. A global survey of trans-resveratrol concentrations in comercial wines. Am. J. Enol. Viticult. 1995, 46, 159-165.

32. Langcake, P.; Pryce, J. The production of resveratrol by Vitis vinifera and other members of the Vitaceae as a response to infection or injury. Physiol. Plant Pathol. 1976, 9, 77-86.

33. Fang, Y.L.; Zhang, A.; Wang, H.; Li, H.; Zhang, Z.W.; Chen, S.X.; Luan, L.Y. Health risk assessment of trace elements in Chinese raisins produced in Xinjiang province. Food Control 2010, 21, 732-739.

34. Wang, J.; Ge, Y.X.; Bao, Y.H. Comparison of characteristics of Vitis amurensis Rupr. varieties. J. Northeast For. Univ. 2004, 32, 29-31.

35. Peng, H.X.; He, P.C.; Huang, F.X.; Zhu, J.H.; Lin, M.J.; Zhang, Y.; Li, H.L. Comparative studies on the progenies with hermaphrodite flower of the interspecific hybrids of Vitis quinquangularis Rehd. South China Fruits 2005, 24, 52-53.

36. He, P.C. Wild grape resources and its utilization in China. Sino-Overseas Grapevine Wine 1999, Special Volume, 1-5.

37. Vastano, B.C.; Chen, Y.; Zhu, N.; Ho, C.T.; Zhou, Z.; Rosen, R.T. Isolation and identification of stilbenes in two varieties of Polygonum cuspidatum. J. Agric. Food Chem. 2000, 48, 253-256.

38. USEPA. Compilation of Air Pollutant Emission Factors: AP-42, Stationary Point and Area Sources, 5th ed.; United States Environmental Protection Agency: Research Triangle Park, NC, USA. 1995; Volume I.

39. MOA. China's Agricultural Yearbook of 2006; Ministry of Agriculture (MOA) of the People's Republic of China: Beijing, China, 2006; p. 192.

40. Baur, J.A.; Sinclair, D.A. Therapeutical potential of resveratrol: the in vivo evidence. Nat. Rev. Drug Discov. 2006, 5, 493-506.

41. OIV. State of the Vitiviniculture World Market, 2010; Available from: http://news.reseauconcept.net/images/oiv_uk/Client/2010_note_conj_mars_tableaux_EN.pdf. Accessed on 21 July 2010.

42. Ector, B.J.; Magee, J.B.; Hegwood, C.P.; Coign, M.J. Resveratrol concentration in Muscadine berries, juice, pomace, purees, seeds and wines. Am. J. Enol. Viticult. 1996, 47, 57-62.

43. Pezet, R.; Cuenat, P.H. Resveratrol in wine: Extraction from skin during fermentation and postfermentation standing of must from Gamay grapes. Am. J. Enol. Viticult. 1996, 47, 287-290. 
44. Tokuşoğlu, Ö.; Ünal, M.K.; Yemiş, F. Determination of the phytoalexin resveratrol (3,5,4`trihydroxystilbene) in peanuts and pistachios by high-performance liquid chromatographic diode array (HPLC-DAD) and gas chromatography-mass spectrometry (GC-MS). J. Agric. Food Chem. 2005, 32, 5003-5009.

45. Counet, C.; Callemien, D.; Collin, S. Chocolate and cocoa: New sources of trans-resveratrol and trans-piceid. Food Chem. 2006, 98, 649-657.

46. Schwekendiek, A.; Spring, O.; Heyerick, A.; Pickel, B.; Pitsch, N.; Peschke, F.; de Keukeleire, D.; Weber, G. Constitutive expression of a grapevine stilbene synthase gene in transgenic hop (Humulus lupulus L.) yields resveratrol and its derivatives in substantial quantities. J. Agric. Food Chem. 2007, 55, 7002-7009.

47. Zhong, J.; Liu, S.J.; Ma, S.S.; Yang, W.; Hu, Y.L.; Wu, Q.; Lin, Z.P. Effect of matrix attachment regions on resveratrol production in tobacco with transgene of stilbene synthase from Parthenocissus henryana. Acta Bot. Sin. 2004, 46, 948-954.

48. Serazetdinova, L.; Oldach, K.H.; Lörz, H. Expression of transgenic stilbene synthases in wheat causes the accumulation of unknown stilbene derivatives with antifungal activity. J. Plant Physiol. 2005, 162, 985-1002.

49. Hüsken, A.; Baumert, A.; Milkowski, C.; Becker, H.C.; Strack, D.; Möllers, C. Resveratrol glucoside (Piceid) synthesis in seeds of transgenic oilseed rape (Brassica napus L.). Theor. Appl. Genet. 2005, 111, 1553-1562.

50. Kobayashi, S.; Ding, C.K.; Nakamura, Y.; Nakajima, I.; Matsumoto, R. Kiwifruits (Actinidia deliciosa) transformed with a Vitis stilbene synthase gene produce piceid (resveratrol-glucoside). Plant Cell Rep. 2000, 19, 904-910.

Sample Availability: Samples of the extracts of three Chinese wild Vitis species (V. amurensis, $V$. pentagona, and $V$. davidii) are available from the authors.

(C) 2011 by the authors; licensee MDPI, Basel, Switzerland. This article is an open access article distributed under the terms and conditions of the Creative Commons Attribution license (http://creativecommons.org/licenses/by/3.0/). 